- 研究报告・

\title{
天童常绿阔叶林定居幼苗存活和生长的关联
}

\author{
刘何铭 1,2 马遵平 1,2 杨庆松 1,2 方晓峰 1,2 林庆凯 ${ }^{1,2}$ 宗 意 1,2 \\ 阿尔达克・阿庆 1,2 王希华 $1,2 *$ \\ 1 (华东师范大学生态与环境科学学院, 上海 200241) \\ 2 (浙江天童森林生态系统国家野外科学观测研究站, 浙江宁波 315114)
}

\begin{abstract}
摘要: 群落幼苗的更新过程是维持群落物种共存的关键环节, 其中幼苗成功定居后的发展阶段是群落幼苗更新过 程的重要组成部分, 对群落可繁殖个体补充格局的形成起着十分重要的作用。然而, 相比于新生幼苗, 群落内定居 幼苗短期死亡率相对较低, 需要较长时间的监测才能完整地了解其存活格局, 所以相关的研究还相对较少。本研 究假设群落内已经成功定居的幼苗的生长状况能够较好地预测其存活情况, 通过分析影响其生长的外在因素, 尝 试间接地估计定居幼苗可能的存活格局, 从而了解定居幼苗的存活和生长过程。为验证该假设, 本文选取浙江天 童20 ha森林动态监测样地内的定居幼苗作为研究对象, 利用广义线性混合模型分析其相对生长速率, 以及生物邻 体因子(同种/异种成树邻体指数, 同种/异种幼苗邻体密度, 同种/异种成树邻体的调落叶产量)和微生境因子(冠层 开度、草本覆盖率、海拔、坡度、坡向、土壤 $\mathrm{pH}$ 、全氮和全磷含量)对定居幼苗短期存活概率的影响, 并利用线性 混合模型分析生物邻体因子和微生境因子对定居幼苗相对生长速率的影响。结果显示, 群落内定居幼苗的相对生 长速率对其本身的短期存活概率有显著正影响, 且其影响程度最高; 冠层开度对群落幼苗相对生长速率有显著正 影响, 且是唯一有显著影响的因子。上述结果说明, 在群落幼苗成功定居后, 其生长状况能够较好地预测其存活情 况, 加之林下较好的光照条件能够促进幼苗的生长, 这可能间接导致在林下光照较好的生境条件下定居幼苗长期 存活的可能性相对较高。
\end{abstract}

关键词: 存活率; 相对生长速率; 广义线性混合模型; 冠层开度; 森林动态样地

\section{Relationships between established seedling survival and growth in ever- green broad-leaved forest in Tiantong}

\author{
Heming Liu ${ }^{1,2}$, Zunping $\mathrm{Ma}^{1,2}$, Qingsong Yang ${ }^{1,2}$, Xiaofeng Fang ${ }^{1,2}$, Qingkai Lin ${ }^{1,2}$, Yi Zong ${ }^{1,2}$, Ar- \\ dak.Aqing ${ }^{1,2}$, Xihua Wang ${ }^{1,2^{*}}$ \\ 1 School of Ecological and Environmental Sciences, East China Normal University, Shanghai 200241 \\ 2 Tiantong National Forest Ecosystem Observation and Research Station, Ningbo, Zhejiang 315114
}

\begin{abstract}
Community seedling regeneration is a crucial process for maintaining species coexistence. The stage from which an established seedling becomes a new reproductive individual is one of the most important components of community regeneration, and influences the community recruitment pattern. However, the short-term mortality of established seedlings is lower than newly germinated seedlings, and previous studies have not been able to analyze the effect of biotic neighborhoods and abiotic micro-habitat factors on established seedling survival perfectly. Therefore, we suggest that the growth status of established seedlings could predict established seedling survival during development, and analyze the effects of these biotic and abiotic factors on established seedling growth, in order to indirectly estimate their effects on established seedling survival. To test this hypothesis, we selected established seedlings in the 20 ha forest dynamics plot in Tiantong as samples. Then, we used generalized linear mixed models to assess the effects of relative growth rate, biotic neighborhood factors (conspecific/heterospecific adult neighborhood indices, density of conspecific/heterospecific seedling neighbors, the amount of conspecific/heterospecific leaf litter from neighbors)
\end{abstract}

收稿日期: 2016-10-05; 接受日期: 2016-11-30

基金项目：国家自然科学基金重大国际合作项目(31210103920)

* 通讯作者 Author for correspondence. E-mail: xhwang@des.ecnu.edu.cn 
and abiotic micro-habitat factors (canopy openness, herbaceous coverage, elevation, slope, aspect, $\mathrm{pH}$ value, total nitrogen and total phosphorus in the soil) on short-term established seedling survival rates. We used linear mixed models to assess the effects of biotic neighborhood factors and abiotic micro-habitat factors on relative growth rates of established seedlings. Results showed that relative growth rates have a significant, positive effect on established seedling survival, and this factor is the most important factor among potential influencing factors. In addition, canopy openness, as only one significant influencing factor, has a positive effect on relative growth rates of established seedlings. These results suggest that the growth status of seedlings could predict established seedling survival during development. Meanwhile, established seedlings prefer to grow in habitat with better light. Therefore, the established seedling survival rate would be higher in the habitat with better light through higher relative growth rates.

Key words: survival rate; relative growth rate; generalized linear mixed models; canopy openness; forest dynamics plot

群落定居幼苗(established seedling)向可繁殖径 级的发展是幼苗更新的最后一步 (Grubb, 1977; Kitajima \& Fenner, 2000)。定居幼苗的存活格局将最 终决定整个群落新的可繁殖个体的补充格局。然而, 该阶段的时间跨度较幼苗定居阶段相对较长，短期 死亡率相对较低, 并且群落内不同物种经历此阶段 所需要的时间差异较大(De-Steven, 1991; AlvarezBuylla \& Martinez-Ramos, 1992; Tanouchi et al, 1994), 因而无法在较短的时间跨度内监测到群落 内大部分物种定居幼苗的最终存活情况。所以需要 通过分析影响群落定居幼苗短期存活的关键因素, 间接地预测定居幼苗可能的存活格局。

许多研究发现, 在群落幼苗定居阶段, 新生幼 苗的高度是决定其能否成功定居的关键因素 (Gerhardt, 1996; Comita \& Hubbell, 2009; Chanthorn et al, 2013; Lu et al, 2015), 而新生幼苗的高度能够 较好地代表幼苗定居前的生长状况, 因此, 新生幼 苗能否成功定居主要受制于其生长状况。由于群落 幼苗定居后需要获取更多资源(von Arnim \& Deng, 1996; Boudell \& Stromberg, 2015; Zahawi et al, 2015), 以便在群落内的个体竞争中占据优势, 所以 生长状况对其存活的影响更加突出。然而, 鲜有研 究将定居幼苗的生长情况与存活状况进行关联。另 外, 生长作为定居幼苗发展的重要特征, 了解其外 部影响因素也很必要。

在群落定居幼苗生长过程中, 由于不同生境的 资源配比可能具有一定差异, 所以在不同生境下, 幼苗间的生长速率可能也会出现差异(Bazzaz，1991; Wright \& Westoby, 1999; Castro et al, 2004), 表现出 一定的生境偏好。已有研究表明, 群落内幼苗的生
长主要受制于光照条件(Kitajima, 1992; Kobe et al, 1995; von Arnim \& Deng, 1996)。在光照充足的条件 下, 幼苗的生长速率较高(Gerhardt, 1996), 而且当 幼苗高度明显超过周围邻体时, 其在光资源竞争中 会明显占据优势, 从而更有可能存活下来(Hubbell et al, 2001)。另外, 土壤养分含量的空间变化也可能 导致不同幼苗个体所获得的营养不同, 从而出现生 长速率的差异(祝燕等, 2009)。除此之外, 在不同微 地形条件下, 地表径流结构会有较大差异, 导致不 同区域的土壤湿度不同(Wright, 2002), 也可能会影 响幼苗的生长。

除了生境偏好外, 生物邻体也可能会影响幼苗 生长速率(Kitajima \& Fenner, 2000)。当周围的资源 不足以供给所有幼苗的生长时, 幼苗间会产生十分 剧烈的资源竞争，以致部分幼苗在竞争中占据优势， 而另一部分幼苗的生长受到抑制，在一段时间后可 能会死亡(祝燕等, 2009)。另外, 根据Janzen-Connell 效应假说(以下简称J-C效应), 同种成树邻体也可能 通过传播专一性病原菌和吸引食草动物捕食 (Janzen, 1970; Connell, 1971), 从而抑制目标幼苗的 生长, 甚至导致其死亡(McCarthy-Neumann \& Kobe, 2010)。然而, 部分研究显示, 由于定居幼苗的各个 器官发育相对完善, 其抵御专一性病原菌和食草动 物侵害的能力也有所加强(Connell, 1971; Condit et al, 2000), 所以J-C效应的影响可能会变弱。此外, 由于受J-C效应影响显著(Comita \& Hubbell, 2009; Kobe \& Vriesendorp, 2011; Bai et al, 2012; Lin et al, 2014), 大部分幼苗可能会在远离母株的低密度区 域定居, 导致定居后的幼苗与母株间的距离相对较 远, 其周围大部分为异种成树邻体。而异种成树邻 
体的聚集可能会阻碍专一性天敌发现和侵害定居 幼苗, 形成明显的异群保护现象(Wills, 1996; Peters, 2003)。

综上所述, 在群落幼苗成功定居后, 由于其短 期死亡率相比于未定居前时明显偏低, 难以在较短 的时间尺度内充分了解影响其存活的外在因素。因 此我们需要先判断其存活是否主要受生长状况的 影响, 然后分析外在因素对生长的影响, 间接地了 解可能影响其存活的因素。为此, 我们选取浙江天 童20 ha森林动态监测样地内的定居幼苗作为监测 对象, 连续3年记录其存活和生长情况, 并收集和 整理其周围的生物邻体和微生境因子, 拟探讨以下 科学问题: (1)在群落幼苗定居后, 其生长速率是否 为影响其短期存活的关键因素? 生物邻体或微生 境因子的影响程度如何? (2)如果定居幼苗的生长 速率是影响其存活的主要因子, 那么哪些生物邻体 或微生境因子会对其生长速率产生影响, 从而间接 影响定居幼苗的存活?

\section{1 材料与方法}

\section{1 研究区概况}

研究区域位于浙江省宁波市鄞州区天童国家 森林公园内。该森林公园地处 $29^{\circ} 48^{\prime} \mathrm{N}, 121^{\circ} 47^{\prime} \mathrm{E}$ 附近, 属于中亚热带季风气候, 四季分明, 年均温 $16.2^{\circ} \mathrm{C}$, 其中 7 月平均气温 $28.1^{\circ} \mathrm{C}$ (全年最热), 1 月平
均气温 $4.2^{\circ} \mathrm{C}$ (全年最冷)。另外, 该区域东临东海, 全 年温和多雨, 年平均降水量 $1,374.7 \mathrm{~mm}$, 大多集中 于夏季6-8月, 冬季降水量相对较少, 雨热同期。土 壤类型为山地黄红壤, 母质主体为中生代沉积岩 (宋永昌和王祥荣, 1995)。常绿阔叶林为公园内主要 植被类型, 沟谷附近也常聚集生长部分落叶阔叶树 种(宋永昌和王祥荣, 1995; Yan et al, 2006), 斑块状 镶嵌于成熟群落内, 形成常绿落叶共存的植物群落 类型(谢玉涁等, 2012)。

天童20 ha森林动态监测样地 (以下简称天童样 地)毗邻天童禅寺, 位于公园核心保护区内, 该区域 植被作为寺院的风水林长期保存, 群落结构完整, 植物种类丰富(杨庆松等, 2011)。样地东西长 $500 \mathrm{~m}$, 南北宽 $400 \mathrm{~m}$, 海拔范围304.26-602.89 m, 落差 $298.63 \mathrm{~m}$, 其间包含两条贯穿南北的山脊。样地整 体地形复杂多变, 环境异质性较高(图1)。2009年对 样地内所有胸径 $(\mathrm{DBH}) \geq 1 \mathrm{~cm}$ 的木本植物进行了每 木调查, 包括鉴定种名、测量胸径以及记录空间坐 标等(杨庆松等, 2011)。

\section{2 幼苗监测样点的设置}

为了了解群落幼苗的更新过程, 在天童样地全 面建成后, 我们于 2011 年8月在样地内设置了187个 幼苗监测样点。监测样点均匀分布于每个 $20 \mathrm{~m} \times 20$ $\mathrm{m}$ 样格的对角点(图1), 但为了避免边缘效应, 并未 在样地边缘 $40 \mathrm{~m}$ 范围内设置监测样点。监测样点内

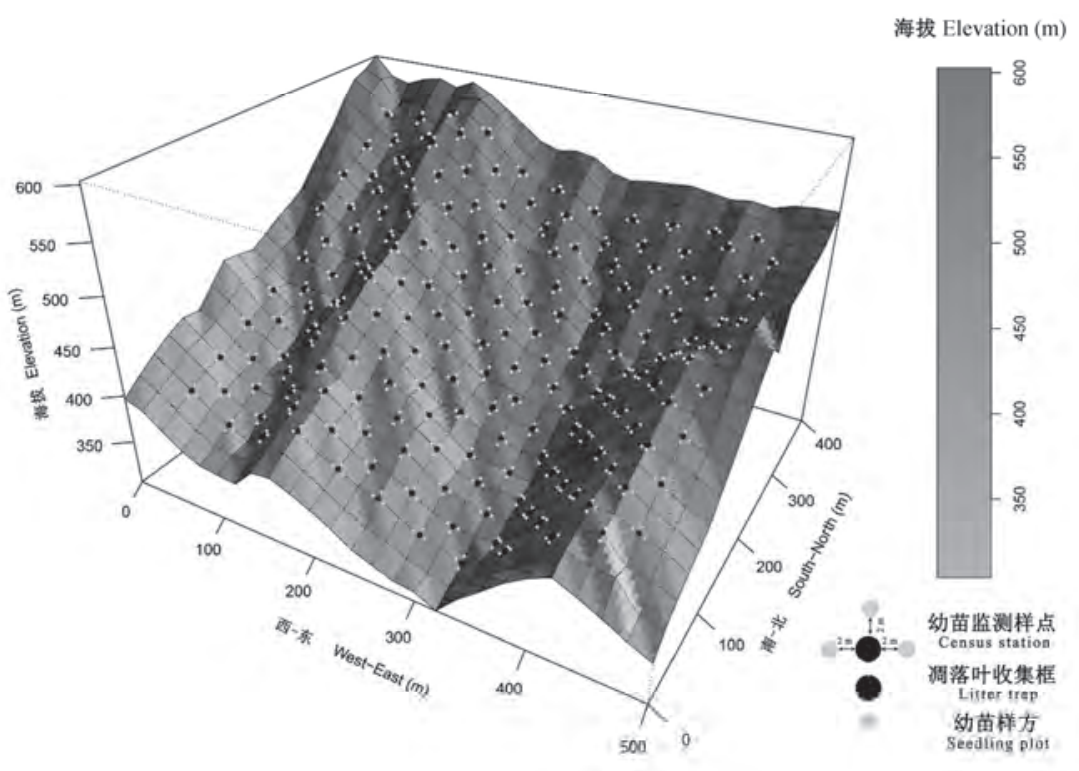

图1 天童20 ha森林动态监测样地地形图及幼苗监测样点分布图

Fig. 1 Topography of 20 ha forest dynamics plot in Tiantong and the distribution of seedling census stations 
包含 1 个 $0.5 \mathrm{~m}^{2}$ 的调落物收集框(中心位置)和距离其 $2 \mathrm{~m}$ 的 3 个 $1 \mathrm{~m} \times 1 \mathrm{~m}$ 的幼苗监测样方(方向随机) (图 1), 共计 187 个调落物收集框和 561 个幼苗监测样 方。此种设置方式能够全面监测天童样地内不同地 形条件下幼苗的更新过程, 并通过监测样点中心点 的调落物收集框, 在不影响幼苗样方地表调落物层 的情况下, 收集幼苗周围的调落叶并估计其产量。

\section{3 监测内容及定居幼苗样本的䇻选}

2011年10月, 我们首先对561个幼苗样方内的 已有木本植物幼苗(胸径DBH $\leq 1 \mathrm{~cm}$ )进行了本底调 查, 包括挂牌、物种鉴定、株高测量、辨别木质部 是否形成(对形成木质部的幼苗进行基径测量)、空 间位置和草本覆盖度记录。2012-2014年, 每年10 月复查株高和存活情况。本研究选择的定居幼苗为 2011年10月本底调查期间, 木质部已基本形成(基 径BD $\geq 1 \mathrm{~mm}$ )并具有多层明显叶痕的幼苗个体(附 录1)。考虑到需要分析同种成树邻体对定居幼苗存 活和生长的影响, 我们首先去除了未能进行物种鉴 定的定居幼苗样本 10 株, 以及在 20 ha动态监测样 地每木调查过程中未出现 (无成年个体)的 3 个物种 (浙皖虎刺(Damnacanthus macrophyllus)、花椒簕 (Zanthoxylum scandens)和虎刺(Damnacanthus indicus))的定居幼苗样本共22株, 这些定居幼苗占所有 定居幼苗样本数的 $2.58 \%$ (附录2)。

\section{4 定居幼苗相对生长速率}

本研究利用定居幼苗的相对生长速率(relative growth rate, RGR)代表其生长情况, 以尽量避免由 于苗龄原因造成的绝对生长量的差异。计算公式 如下:

$$
\overline{R G R_{i}}=\left[\ln \left(\text { Height }_{i}\right)-\ln \left(\text { Height }_{i-1}\right)\right] /\left(t_{i}-t_{i-1}\right)
$$

式中, $i$ 为调查年份, Height为幼苗株高, $t_{i}-t_{i-1}$ 为两 次调查的间隔时间，均为1年。

在篮选影响定居幼苗短期存活的关键因素时, 需要分析幼苗相对生长速率(生长状况)对存活的影 响。但幼苗在调查过程中会出现死亡的现象, 导致 无法获取当年的相对生长速率, 因此, 我们选择其 前一年的相对生长速率代替当年的相对生长速率 作为影响幼苗存活的生长速率因子。其中2011年10 月至2012年10月死亡的幼苗个体, 其前一年的相对 生长速率无法计算(研究期间以外), 所以本研究并
未分析该时间段内定居幼苗短期存活的影响因素。 在分析影响幼苗生长的因素时, 我们筛选的是一直 存活的定居幼苗个体，可以计算每株幼苗当年的相 对生长速率, 因此我们选择当年的相对生长速率代 表定居幼苗的生长情况。

\section{5 生物邻体因子}

\subsection{1 目标幼苗周围同种/异种成树邻体指数和幼 苗邻体密度}

为了辨别幼苗周围成树邻体是否通过 J-C 效应 影响定居幼苗的存活和生长, 本研究参考相关的研 究, 将成树邻体定义为幼苗所在幼苗样方中心点周 围10 m范围内胸径 $\geq 1 \mathrm{~cm}$ 的个体(Comita \& Hubbell, 2009; Lin L et al, 2012; Lin F et al, 2014), 并将 其分为同种成树邻体和异种成树邻体, 分别计算其 成树邻体指数。由于其距离幼苗越近、胸径越大, 对 幼苗存活和生长的影响越大(Canham et al, 2004), 所以成树邻体指数为考虑距离权重的成树邻体胸 高断面积和。计算公式如下:

$$
A=\sum_{j=1}^{N} B A_{j} / \text { DISTANCE }_{j}
$$

式中, $N$ 为成树邻体数量, $B A$ 为成树邻体的胸高断面 积, DISTANCE为成树邻体到目标幼苗所在幼苗样 方中心点的距离, 当成树邻体生长在幼苗样方内, $A$ 会异常增大, 所以此时我们将DISTANCE调整为 0.5 $\mathrm{m}$ (假设成树邻体在 $1 \mathrm{~m} \times 1 \mathrm{~m}$ 的幼苗样方边缘)。

同种/异种幼苗邻体密度作为衡量密度制约格 局的重要指标(Comita \& Hubbell, 2009; Kobe \& Vriesendorp, 2011; Bai et al, 2012; Lu et al, 2015), 也 可能是影响定居幼苗生长的重要因子。为此我们调 查了与其处于同一幼苗样方内的同种和异种幼苗 密度(包括非定居幼苗), 作为同种和异种幼苗邻体 密度因子。

\subsection{2 同种/异种叶调落量因子}

同种成树邻体产生的调落叶可能携带专一性 的病原菌和昆虫, 抑制其周围同种定居幼苗的存活 和生长(Xiong \& Nilsson, 1997; García-Guzmán \& Benítez-Malvido, 2003); 而大量的其他异种调落叶 有可能通过改变微生境而间接影响其周围定居幼 苗的存活和生长(Xiong \& Nilsson, 1997)。为此, 我 们需要估计幼苗周围同种和异种调落叶的产量, 从 而分析其对定居幼苗存活和生长的影响。我们利用 
2011年10月至2014年10月期间，187个调落物框每 两个星期收集一次的调落叶分种称量 ${ }^{(2)(3)}$ ，计算幼 苗存活或生长时段内其所对应的调落叶框收集到 的同种/异种调落叶总量(干重), 作为同种/异种叶 调落量因子。

\section{6 微生境因子}

由于群落幼苗生长过程对于微生境十分敏感, 所以本研究仔细测量了定居幼苗周围的微生境因 子, 包括幼苗样方上部的冠层开度(光环境), 所处 的海拔、坡向和坡度, 样方内的草本覆盖度, 以及 周围土壤的 $\mathrm{pH}$ 值、全氮含量和全磷含量, 力求获得 较为完整的微生境信息。其中, 幼苗样方内精确的 坡度和坡向数据是在幼苗调查期间(2014年1-5月), 利用具有两向刻度调节的三脚架(A650F, BENRO, 中国)和地质罗盘仪(DQL-11), 通过计算每个幼苗 样方中心位置与水平面的二面角(坡度), 以及坡面 法线在水平面的投影方向(坡向)获得的 ${ }^{(0}$ 。另外, 在 三脚架上安装配有鱼眼镜头(AF DX 10.5mm F2.8G ED, Nikon, 日本)的单反相机(D70, Nikon, 日本), 拍摄幼苗样方中心点 $0.5 \mathrm{~m}$ 高度以上的 180 度全景冠 层照片。然后利用冠层开度分析软件(Regent Instruments, WinSCANOPY2013a, 加拿大)分析冠层 照片, 计算出幼苗样方上部的冠层开度 ${ }^{(5)}$ 。除此之外, 2008-2011年天童样地建设期间, 已对每个20 m × $20 \mathrm{~m}$ 样方顶点的海拔(全站仪)、土壤 $\mathrm{pH}$ 值(土水比例 1:5混合后, 利用电极法测定)、全磷 $\left(\mathrm{SAN}^{++}, \mathrm{Skalar}\right.$, 荷兰)和全氮(vario MICRO cube, Elementar, 德国) (详见张娜等, 2012)进行测量和取样分析。由于本研 究的幼苗样方设置于部分 $20 \mathrm{~m} \times 20 \mathrm{~m}$ 样方顶点附 近(图1), 因此, 幼苗样方的海拔和土壤理化性质 (土壤 $\mathrm{pH}$ 值、全氮和全磷含量), 均采用对应顶点的 数据。草本覆盖度是在幼苗调查过程中进行实地记 录的。基本情况如表 1 。

\footnotetext{
(1) 王樟华 (2013) 浙江天童常绿阔叶林调落物量的时空分布特征. 硕 士学位论文, 华东师范大学, 上海.

(2) 赵青青 (2014) 浙江天童常绿阔叶林调落物动态及调落叶空间扩散 模型研究. 硕士学位论文, 华东师范大学, 上海.

(3) 董舒 (2016) 天童常绿阔叶林 6 个优势种调落量及养分特征研究. 硕士学位论文, 华东师范大学, 上海.

(4) 袁铭姣 (2016) 极端天气对天童常绿榈叶林调落物量的影响. 硕士 学位论文, 华东师范大学, 上海.

(5) 邢九州 (2015) 林内光环境的精确测量方法及时空异质性. 硕士学
} 位论文, 华东师范大学, 上海.

\section{7 统计分析}

\subsection{1 短期存活影响因素模型}

由于需要分析幼苗相对生长速率以及生物邻 体和微生境因子对群落定居幼苗短期存活情况(二 项分布数据)的影响, 加之群落幼苗是由群落内不 同空间、不同调查时间，以及不同物种的幼苗共同 组成的, 为此我们需要构建能够综合各分组变量并 转换为二项分布概率的回归模型。本研究选择二项 分布族(binomial distribution)的广义线性混合模型 (generalized linear mixed models), 用以分析幼苗相 对生长速率、生物邻体和微生境因子对群落定居幼 苗短期存活情况的影响。其中, 因变量被定义为不 同物种(层次五)的幼苗，在不同调查年份间(层次 四), 其在不同监测样点内 (层次三)的幼苗样方中 (层次二)的个体(层次一)存活情况(存活为 1 , 死亡为 $0)$, 该数据类型属于五层巣式数据。自变量为可能影 响其存活的因子, 包括幼苗前一年的相对生长速率, 生物邻体因子如同种和异种成树邻体指数、同种和异 种幼苗邻体密度、同种和异种调落叶产量, 及微生境 因子如冠层开度、草本覆盖度、海拔、坡度、坡向、 土壤 $\mathrm{pH}$ 值、土壤全氮含量、土壤全磷含量。综上所 述, 广义线性混合模型应设计为:

$$
Y_{i j p q k} \sim \operatorname{binomial}\left(1, \pi_{i j p q k}\right)
$$

$\operatorname{logit}\left(\pi_{i j p q k}\right)=[\alpha+\beta \times x]_{\text {fixed.part }}+\left[\mu_{j|p| q \mid k}+\mu_{p|q| k}+\mu_{q \mid k}+\mu_{k}\right]_{\text {randompart }}$

式中, $Y_{i j p q k}$ 为物种 $k$ 在 $q$ 调查年份, 其监测样点 $p$ 内的 幼苗样方 $j$ 中的幼苗个体 $i$ 的存活情况(存活为 1 , 死亡 为0), $\pi_{i j p q k}$ 为定居幼苗 $i$ 的存活概率。公式(4)中随机 项为物种 $k\left(\mu_{k}\right)$, 调查年份 $q\left(\mu_{q \mid k}\right)$, 幼苗监测样点 $p\left(\mu_{p|q| k}\right)$ 和幼苗样方 $j\left(\mu_{j|p| q \mid k}\right)$ 。其中, 幼苗样方 $j$ 包含于 监测样点 $p$ 内, 幼苗监测样点 $p$ 包含于调查年份 $q$ 内, 调查年份 $q$ 包含于物种 $k$ 内(Zuur et al, 2009)。固定项 包括截距 $\alpha$ 和潜在解释变量 $x$ 的系数 $\beta$ 。

\subsection{2 生长影响因素模型}

由于需要了解生物邻体和微生境因子对群落 定居幼苗生长情况的影响, 而群落幼苗的生长状况 (相对生长速率) 是正态分布数据, 为此, 本研究选 择了线性混合模型(linear mixed models)。其中, 因 变量为幼苗当年的相对生长速率, 分组类型与短期 存活影响因素模型相同, 也为五层巣式数据。自变 
表1 幼苗样方微生境因子

Table 1 Micro-habitat factors of seedling plots

\begin{tabular}{lllll} 
微生境因子 & $\begin{array}{l}\text { 最大值 } \\
\text { Maximum value }\end{array}$ & $\begin{array}{l}\text { 最小值 } \\
\text { Minimum value }\end{array}$ & $\begin{array}{l}\text { 平均值 } \\
\text { Mean }\end{array}$ & $\begin{array}{l}\text { 标准差 } \\
\text { Standard deviation }\end{array}$ \\
\hline Micro-habitat factors & 35.31 & 2.58 & 9.09 & 3.86 \\
冠层开度 Canopy openness (\%) & 572.28 & 321.89 & 441.87 & 53.9 \\
海拔 Elevation $(\mathrm{m})$ & 82.65 & 4.00 & 35.08 & 11.98 \\
坡度 Slope $\left(^{\circ}\right)$ & 318.92 & 30.00 & 185.93 & 54.86 \\
坡向 Aspect $\left({ }^{\circ}\right)$ & 100.00 & 0.00 & 20.76 & 24.94 \\
草本覆盖度 Herbaceous coverage (\%) & 10.04 & 0.95 & 3.15 & 1.27 \\
全氮 Total nitrogen (g/kg) & 0.79 & 0.02 & 0.26 & 0.13 \\
全磷 Total phosphorus $(\mathrm{g} / \mathrm{kg})$ & 5.26 & 3.50 & 4.14 & 0.25 \\
$\mathrm{pH}$ 值 $\mathrm{pH}$ value & & &
\end{tabular}

坡向为以北方向为起点的顺时针旋转角度。

Aspect is the clockwise rotation from the north.

量也是可能影响其生长的生物邻体和微生境因子。 综上所述, 线性混合模型应设计为:

$$
R G R_{i j p q k}=[\alpha+\beta \times x]_{\text {fixed.part }}+\left[\mu_{j|p| q \mid k}+\mu_{p|q| k}+\mu_{q \mid k}+\mu_{k}\right]_{\text {random.part }}
$$

式中, $R G R_{i j p q k}$ 为物种 $k$ 在调查年份 $q$ 间, 其幼苗监测 样点 $p$ 内的幼苗样方 $j$ 中的幼苗个体 $i$ 的相对生长速 率, 而随机项和固定项与短期存活影响因素模型 相同。

\subsection{3 模型篮选和分析}

由于群落幼苗成功定居后, 影响其存活和生长 的潜在影响因子数量都相对较多, 可能存在多重共 线性的问题。为此, 本文采用全子集回归的方法 (Burnham \& Anderson, 2002), 篮选所有子集模型中 的一个或多个最优模型, 组成最优模型组(去除具 有共线性或无关的潜在影响因子), 综合分析最优 模型组中解释变量的平均估计量 (model-averaged estimators) 或二阶平均估计量 (second modelaveraged estimator), 用以笁选主要影响因子(显著 影响)。然后根据平均估计量的正负了解其影响的方 式(显著正影响或负影响)。另外, 根据所有潜在因子 的 $A I C_{C}$ 权重确定其影响程度。

全子集回归模型即将所有潜在影响因子进行 不重复的随机组合(附录3公式1)。然后依次对组合 形成的回归模型进行分析, 获得每个模型的 $A I C$ (Akaike information criterion)值。由于本研究中部分 物种尺度的模型的样本量较小(样本数/潜在影响因 子的个数 $\leq 30)$, 所以需要将 $A I C$ 转换成二阶即 $A I C_{c}$ (附录3公式2) (Blau \& Neely, 1975)进行模型篮选和 相关运算 $\left(A I C_{c}\right.$ 用法与 $A I C$ 完全一样) (Burnham \&
Anderson, 2002)。另外, 根据附录3公式3和4计算所 有模型的 $\triangle A I C_{c}$ 值和权重 $w_{i}$, 用以篮选最优模型和 分析潜在影响因子。

根据全子集中每个回归模型的 $A I C_{c}$ 权重 $w_{i}$ 计算 每个潜在影响因子的相对权重 $w_{+}(j)$ (附录3公式5和 6) (Burnham \& Anderson, 2002), 用以表示各潜在影 响因子对于定居幼苗存活和生长(因变量变化)的影 响程度, 如果相对权重 $w_{+}(j)$ 的值相同, 则比较平均 估计量或二阶平均估计量。

篮选所有子集模型中 $\triangle A I C_{c} \leq 2$ 的模型组成最 优模型组 $\left(\Delta A I C_{c}\right.$ 值相差 2 的模型间没有显著性差异) (Burnham \& Anderson, 2002), 分析最优模型组内各 个潜在影响因子对于定居幼苗存活和生长(因变量 变化)的影响方式, 即分析各因子回归系数的显著 程度及其正负。由于本研究采用的是全子集回归的 方法, 所以最优模型可能是一个或者多个, 需要利 用平均估计量 $\bar{\beta}_{j}$ (附录3公式7,8和9), 或二阶平均 估计量 $\tilde{\bar{\beta}}_{j}$ (附录3公式10) (Burnham \& Anderson, 2002), 综合考虑各潜在影响因子在最优模型组内 全部的回归系数, 用以分析其对于定居幼苗存活和 生长(因变量变化)的影响方式。当 $\hat{\bar{\beta}}_{j}$ 或 $\tilde{\bar{\beta}}_{j} \neq 0$ 时, 说 明该潜在影响因子对定居幼苗的存活和生长(因变 量变化)有显著影响, 即为主要影响因子; 其中, 当 $\hat{\bar{\beta}}_{j}$ 或 $\tilde{\bar{\beta}}_{j}>0$ 时, 为显著正影响; 如果小于 0 , 则为 显著负影响。如果等于 0 , 则无显著影响。

所有统计分析均采用 $\mathrm{R}$ 软件完成，其中广义线 性混合模型和线性混合模型分析分别采用 $\mathrm{R}$ 软件的 


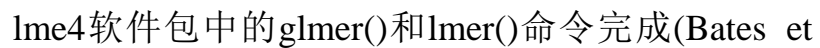
$\mathrm{al}, 2013)$, 统计检验的显著性水平为 $\alpha=0.05$ 。

\section{2 结果}

\section{1 群落内定居幼苗的年际存活和生长动态}

2011年10月本底调查时, 共调查已经成功定居 的实生木本幼苗1,239株(图2A) (其中10株个体未能 鉴定), 分别属于 30 科53属77种。从本底调查至2014 年10月最后一次复查, 3年间共死亡 344 株(图2A), 年均死亡率为 $10.2 \pm 0.2 \%$ 。另外, 年均相对生长速 率为6.6 $\pm 1.4 \mathrm{~cm} \cdot \mathrm{m}^{-1} \cdot \mathrm{yr}^{-1}$, 且 3 年间无显著差异(图 2B)。

\section{2 各因子对定居幼苗短期存活的影响}

群落定居幼苗的短期存活率主要受其相对生 长速率的显著正影响, 即幼苗相对生长速率的升高 会提高其存活率。另外, 异种成树邻体指数的升高 也会显著提高定居幼苗的短期存活率, 但影响程度 低于相对生长速率。其他潜在影响因子对定居幼苗 短期存活率无显著影响(图3)。

\section{3 各因子对定居幼苗生长的影响}

在群落尺度上，定居幼苗的相对生长速率会随 着冠层开度的增加而显著增加, 且是唯一对定居幼
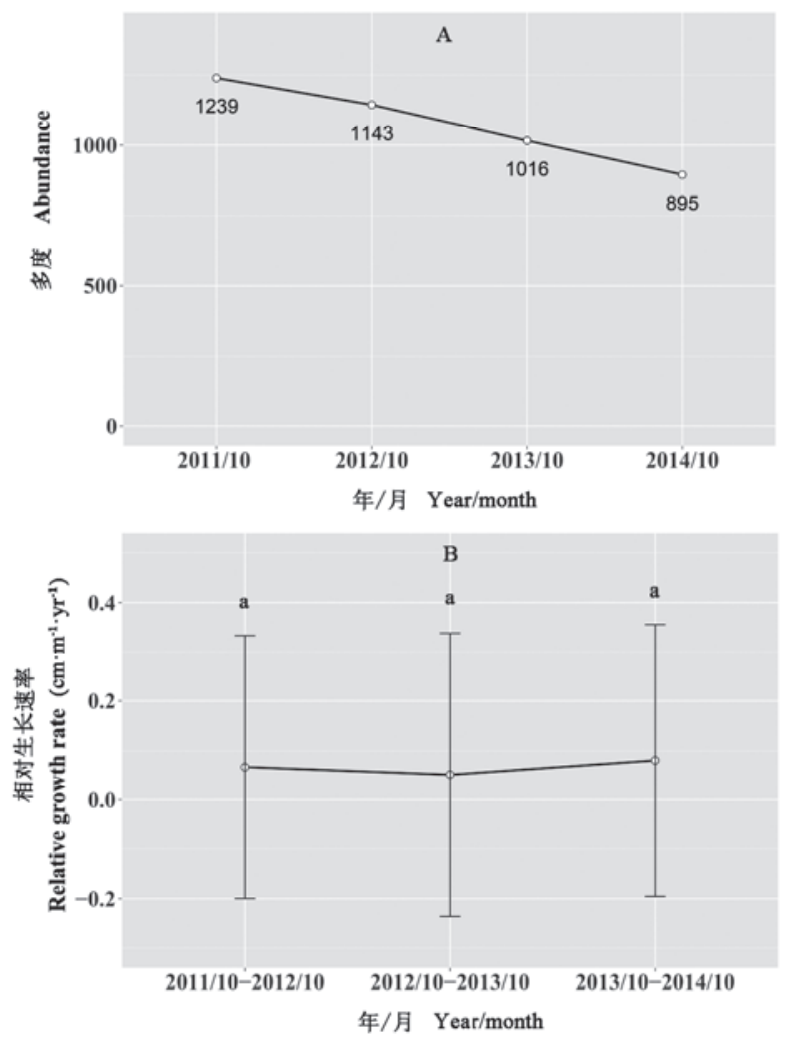

图 2 定居幼苗多度(A)和相对生长速率(B)随时间的动态 变化

Fig. 2 Temporal dynamic changes of abundance (A) and relative growth rate (B) of the established seedlings

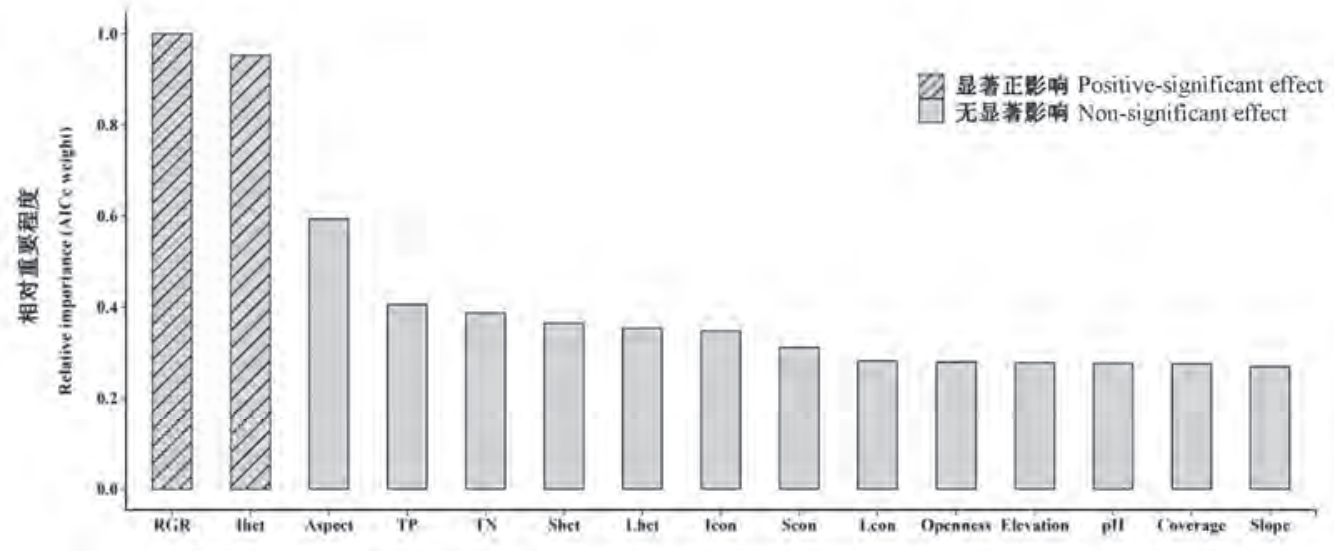

图3 各因子对群落内定居幼苗短期存活概率的影响。AICc的相对权重为该因子的影响程度(按影响程度降序排列)。RGR: 前 一年相对生长速率; Icon: 同种成树邻体指数; Ihet: 异种成树邻体指数; Scon: 同种幼苗邻体密度; Shet: 异种幼苗邻体指 数; Lcon: 同种凋落叶产量; Lhet: 异种凋落叶产量; Coverage: 幼苗样方内的草本覆盖度; Openness: 冠层开度; Slope: 坡 度; Aspect: 坡向(经 $\cos (\alpha)+1.1$ 转换); Elevation: 幼苗监测样点周围的海拔; pH: 土壤pH值; TN: 土壤全氮含量; TP: 土壤全 磷含量。

Fig. 3 Effects of factors on established seedlings survival in the community. The AICc weight indicates the relative importance of each factor. The ranking of potential factors in the $\mathrm{X}$ axis is ordered by the AICc weight. RGR, Relative growth rate in the previous year; Icon, Conspecific adult neighborhood indices; Ihet, Heterospecific adult neighborhood indices; Scon, Density of conspecific seedling neighbors; Shet, Density of heterospecific seedling neighbors; Lcon, Amount of conspecific leaf litter; Lhet, Amount of heterospecific leaf litter; Coverage, Coverage of herb in the focal seedling plot; Openness, Canopy openness; Aspect, Transformed by $\cos (\alpha)+1.1 ; \mathrm{pH}, \mathrm{pH}$ value in the soil; TN, Total nitrogen in the soil; TP, Total phosphorus in the soil. 


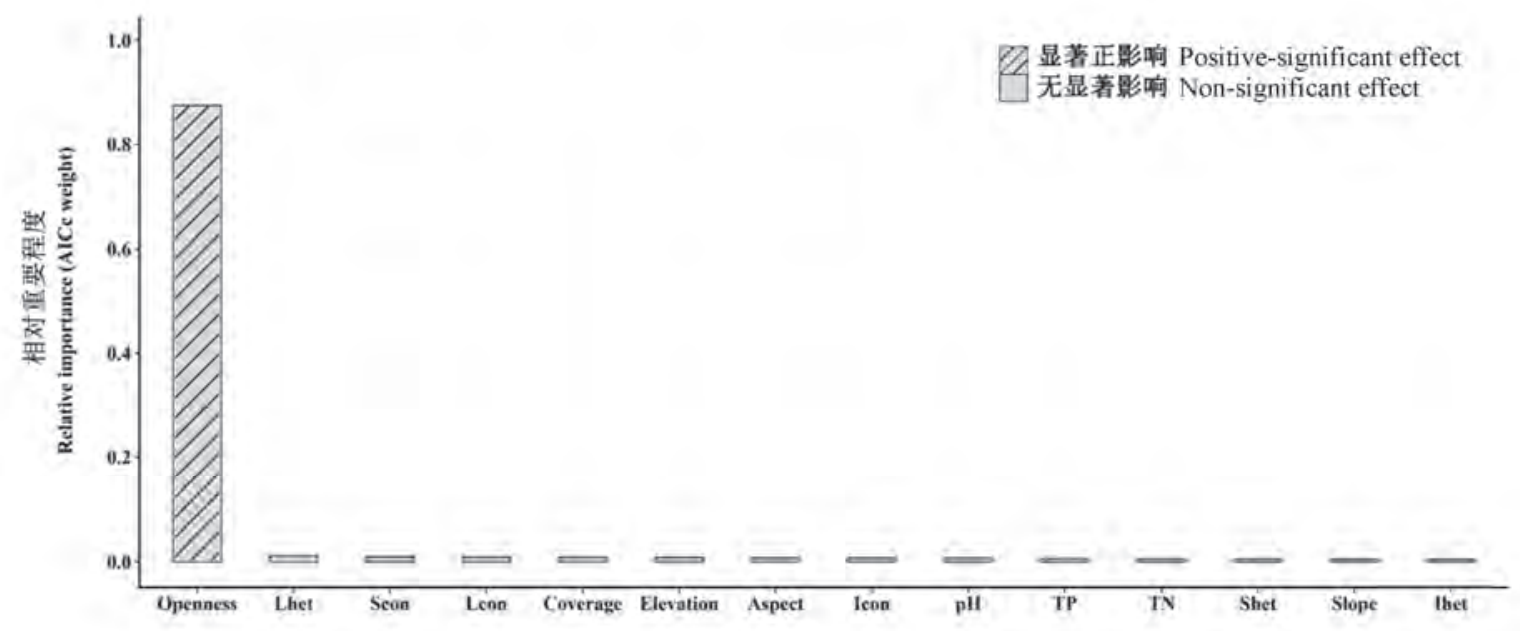

图4 生物邻体和微生境因子对群落内定居幼苗相对生长速率的影响。AICc的相对权重为该因子的影响程度(按影响程度降序 排列)。Icon: 同种成树的邻体指数; Ihet: 异种成树的邻体指数; Scon: 同种幼苗邻体密度; Shet: 异种幼苗邻体指数; Lcon: 同种凋落叶产量; Lhet: 异种凋落叶产量; Coverage: 幼苗样方内的草本覆盖度; Openness: 冠层开度; Slope: 坡度; Aspect: 坡向(经 $\cos (\alpha)+1.1$ 转换); Elevation: 幼苗监测样点周围的海拔; pH: 土壤 $\mathrm{pH}$ 值; TN: 土壤全氮含量; TP: 土壤全磷含量。

Fig. 4 Effects of biotic neighborhood and micro-habitat factors on the relative growth rate of established seedlings in the community. The AICc weight indicates the relative importance of each factor. The ranking of potential factors in the $\mathrm{X}$ axis is ordered by the AICc weight. Icon, Conspecific adult neighborhood indices; Ihet, Heterospecific adult neighborhood indices; Scon, Density of conspecific seedling neighbors; Shet, Density of heterospecific seedling neighbors; Lcon, Amount of conspecific leaf litter; Lhet, Amount of heterospecific leaf litter; Coverage, Coverage of herb in the focal seedling plot; Openness, Canopy openness; Aspect, Transformed by $\cos (\alpha)+1.1 ; \mathrm{pH}, \mathrm{pH}$ value in the soil; TN, Total nitrogen in the soil; TP, Total phosphorus in the soil.

苗相对生长速率有显著性影响的因子，其他因子都 没有显著影响(图4)。

\section{3 讨论}

通过分析发现, 定居幼苗的相对生长速率是影 响其短期存活最重要的因素, 随着相对生长速率的 增加, 其存活率也显著提高。这说明即使在较短的 时间尺度内(较低的死亡率), 群落定居幼苗的存活 仍然受其生长状况的显著影响。在分析影响群落定 居幼苗生长的外在因素时我们发现, 在群落尺度上, 冠层开度是影响群落定居幼苗相对生长速率的唯 一因子, 在林下冠层开度大的位置, 群落定居幼苗 的相对生长速率显著提高。

在分析影响群落定居幼苗短期存活的因素时, 我们发现微生境因子并未对群落定居幼苗的短期 存活产生显著影响。可能的原因是幼苗定居后, 其 短期死亡率会大幅下降(De-Steven，1991; Alvarez-Buylla \& Martinez-Ramos, 1992; Kitajima \& Fenner, 2000)。由于死亡率低(本研究中定居幼苗的 年均死亡率仅为 $10.2 \pm 0.2 \%$ ), 所以微生境因子对 群落定居幼苗存活的影响难以在较短的时间尺度
内表现出来, 需要进行较长时间的监测。

另外, J-C效应导致的密度制约和距离制约格局 在定居幼苗的短期存活格局中并未体现。密度制约 格局未形成的主要原因可能是群落定居幼苗的多 度与频度(附录2)呈现极显著正相关 $(r=0.97, P<$ 0.001), 多度大、频度小的聚集格局较少出现 (ЯрошенкоПД, 1966), 加之定居幼苗相比于未定居 的幼苗, 其植株抵抗天敌侵害的能力更强(Kit- ajima\& Fenner, 2000), 从而导致专一性天敌难以集中 侵害定居幼苗个体并造成其大量死亡, 形成密度制 约格局; 而距离制约格局未形成的主要原因可能是 由于群落幼苗在定居前的阶段已经远离母株 (Comita \& Hubbell, 2009; Kobe \& Vriesendorp, 2011; Bai et al, 2012; Lin F et al, 2014), 使专一性天敌难 以侵害。然而, 由于定居幼苗远离母株, 造成异种 成树成为围绕在其周围的重要成树类型。在分析影 响定居幼苗短期存活的因素时, 我们发现异种成树 邻体指数上升, 会显著提高定居幼苗的短期存活 率。可能的原因是异种成树个体的聚集能够有利地 阻隔专一性天敌的侵害, 形成明显的异群保护现象 (Hubbell \& Foster, 1986; Kochummen et al, 1990)。然 
而, 异种成树邻体对定居幼苗短期存活的影响程度 要小于相对生长速率, 相对生长速率能够更好地解 释定居幼苗的短期存活情况。

由于定居幼苗已经成功定植, 所以在较短的时 间尺度上, 我们并未观测到大部分生物邻体和微生 境因子对定居幼苗存活的明显影响。然而, 幼苗自 身的相对生长速率却在较短的时间尺度上对定居 幼苗存活产生了十分显著的正影响(当幼苗的相对 生长速率明显高于周围同种同阶段个体时, 其存活 率也会上升)。说明定居幼苗的相对生长速率是影响 幼苗存活的关键因素, 加之幼苗相对生长速率对外 部生物邻体和微生境因子影响的敏感性较高 (Turner, 1990; Berkowitz et al, 1995), 所以本研究通 过分析不同因子对定居幼苗相对生长速率的影响, 从而间接推测定居幼苗的存活格局是可行的。

通过分析发现, 在群落尺度上冠层开度是唯一 显著影响定居幼苗相对生长速率的因素。随着冠层 开度的增加, 幼苗的相对生长速率也会增加, 说明 较好的光照条件能够促进群落内定居幼苗的生长。 虽然本群落内存在较多的耐阴种(刘何铭等, 2015), 根据以往的研究, 在高光环境下耐阴种幼苗的生长 会受到抑制(Walters et al, 1993; Kitajima，1994; Walters \& Reich, 1996), 但由于幼苗样方顶部的冠 层开度最大仅为 $35.31 \%$ (表1), 未达到仅适宜阳生 种存活和生长的高光或全光环境(冠层开度> 40\%) (Ellenberg, 1974)。而在非高光环境下, 适量增加的 光照也会促进耐阴种幼苗的生长(Canham, 1988)。 所以光照成为影响该区域群落定居幼苗生长重要 的外在因素。另外, 不同物种间定居幼苗相对生长 速率的差异是影响群落定居幼苗生长的重要内在 因素(附录4), 但这并未干扰冠层开度作为重要的外 在因素对于其相对生长速率的影响程度和方式。

许多研究显示, 当光资源成为植物生长的限制 因素时, 植物体通常会选择快速生长以获取更多的 光资源存活下来, 形成生长率高、存活率也高的现 象(Walters \& Reich, 1996; Hubbell et al, 2001; Lin F et al, 2014; Ley-López et al, 2016)。本研究中光照是 限制天童群落定居幼苗生长的唯一因素。通过分析 我们也发现, 在群落水平上, 定居幼苗的相对生长 速率与存活率呈现极显著的正相关(附录5), 说明天 童群落大部分物种的定居幼苗会选择快速生长, 从 而获取更多的光资源。
综上所述, 群落内定居幼苗的存活主要受生长 状况的影响。相对生长速率较高的定居幼苗, 其存 活的可能性也相对较大, 而林下光环境较好的区域, 幼苗的相对生长速率也较高, 因此光环境可能会间 接地影响定居幼苗的存活格局。另外，由于光环境 是通过促进定居幼苗生长, 从而逐渐提升幼苗存活 的可能性, 该过程需要在较长的时间尺度上才能检 验, 所以在本研究中我们并未发现光环境对于定居 幼苗短期存活产生显著的直接影响。除此之外, 本 研究所考虑的生物邻体和环境因子并不全面, 其对 定居幼苗短期存活率和相对生长速率变化的解释 程度也都相对较小(附录6)。许多未考虑的外界因素 也可能通过影响定居幼苗的生长从而间接地影响 其存活, 光环境也同样可能通过影响其他外界因素 间接影响定居幼苗的存活。为此, 在以后的研究中 应该尝试考虑更多的生物邻体和环境因子, 寻找其 他可能的影响因素。

致谢: 十分感谢邢九州同学为本研究提供的冠层开 度数据, 以及王樟华、赵青青、董舒和袁铭皎同学 为本研究提供的调落物数据。

\section{参考文献}

Alvarez-Buylla ER, Martinez-Ramos M (1992) Demography and allometry of Cecropia obtusifolia, a neotropical pioneer tree-an evaluation of the climax-pioneer paradigm for tropical rain forests. Journal of Ecology, 80, 275-290.

Bai XJ, Queenborough SA, Wang XG, Zhang J, Li BH, Yuan ZQ, Xing DL, Lin F, Ye J, Hao ZQ (2012) Effects of local biotic neighbors and habitat heterogeneity on tree and shrub seedling survival in an old-growth temperate forest. Oecologia, 170, 755-765.

Bates D, Maechler M, Bolker B, Walker S (2013) lme4: Linear mixed-effects models using Eigen and S4. R package version 3.2.1. http://lme4.r-forge.r-project.org/. (accessed on 2016-10-01)

Bazzaz FA (1991) Habitat selection in plants. The American Naturalist, 137, 116-130.

Berkowitz AR, Canham CD, Kelly VR (1995) Competition vs. facilitation of tree seedling growth and survival in early successional communities. Ecology, 76, 1156-1168.

Blau GE, Neely WB (1975) Mathematical model building with an application to determine the distribution of Dursban insecticide added to a simulated ecosystem. Advances in Ecological Research, 9, 133-163.

Boudell JA, Stromberg JC (2015) Impact of nitrate enrichment on wetland and dryland seed germination and early seedling development. Journal of Vegetation Science, 26, 452-463. 
Burnham KP, Anderson DR (2002) Model Selection and Multimodel Inference: A Practical Information-Theoretical Approach, 2nd edn. Springer, New York.

Canham CD (1988) Growth and canopy architecture of shade-tolerant trees: response to canopy gaps. Ecology, 69, 786-795.

Canham CD, LePage PD, Coates KD (2004) A neighborhood analysis of canopy tree competition: effects of shading versus crowding. Canadian Journal of Forest Research, 34, 778-787.

Castro J, Zamora R, Hódar JA, Gómez JM (2004) Seedling establishment of a boreal tree species (Pinus sylvestris) at its southernmost distribution limit: consequences of being in a marginal Mediterranean habitat. Journal of Ecology, 92, 266-277.

Chanthorn W, Caughlin T, Dechkla S, Brockelman WY (2013) The relative importance of fungal infection, conspecific density and environmental heterogeneity for seedling survival in a dominant tropical tree. Biotropica, 45, 587-593.

Comita LS, Hubbell SP (2009) Local neighborhood and species' shade tolerance influence survival in a diverse seedling bank. Ecology, 90, 328-334.

Condit R, Ashton PS, Baker P, Bunyavejchewin S, Gunatilleke S, Gunatilleke N, Hubbell SP, Foster RP, Itoh A, LaFrankie JV (2000) Spatial patterns in the distribution of tropical tree species. Science, 288, 1414-1418.

Connell JH (1971) On the role of natural enemies in preventing competitive exclusion in some marine animals and in rain forest trees. In: Dynamics of Populations (eds den Boer PJ, Gradwell GR), pp. 298-312. Centre for Agricultural Publishing and Documentations, Wageningen.

De-Steven D (1991) Experiments on mechanisms of tree establishment in old-field succession: seedling survival and growth. Ecology, 72, 1076-1088.

Ellenberg H (1974) Scripta Geobotanica. Verlag Erich. Goltze, Göttingen. (in German)

García-Guzmán G, Benítez-Malvido J (2003) Effect of litter on the incidence of leaf-fungal pathogens and herbivory in seedlings of the tropical tree Nectandra ambigens. Journal of Tropical Ecology, 19, 171-177.

Gerhardt K (1996) Effects of root competition and canopy openness on survival and growth of tree seedlings in a tropical seasonal dry forest. Forest Ecology and Management, 82, 33-48.

Grubb PJ (1977) The maintenance of species-richness in plant communities: the importance of the regeneration niche. Biological Reviews, 52, 107-145.

Hubbell SP, Foster RB (1986) Biology, chance, and history and the structure of tropical rain forest tree communities. In: Community Ecology (eds Diamond J, Case JT), pp. 314-329. Harper \& Row, New York.

Hubbell SP (2001) The unified neutral theory of biodiversity and biogeography. Princeton University Press, Princeton \& Oxford.

Hubbell SP, Ahumada JA, Condit R, Foster RB (2001) Local neighborhood effects on long-term survival of individual trees in a neotropical forest. Ecological Research, 16, 859-875.

Janzen DH (1970) Herbivores and the number of tree species in tropical forests. The American Naturalist, 104, 501-528.

Kitajima K (1992) The importance of cotyledon functional morphology and patterns of seed reserve utilization for the physiological ecology of neotropcial tree seedling. $\mathrm{PhD}$ dissertation, Illinois Urbana-Champaign, Illinois.

Kitajima K (1994) Relative importance of photosynthetic traits and allocation patterns as correlates of seedling shade tolerance of 13 tropical trees. Oecologia, 98, 419-428.

Kitajima K, Fenner M (2000) Ecology of seedling regeneration. In: Seeds: the Ecology of Regeneration in Plant Communities (ed. Fenner M), pp. 331-359. CABI, Oxon \& New York.

Kobe RK, Pacala SW, Silander JA, Canham CD (1995) Juvenile tree survivorship as a component of shade tolerance. Ecological Applications, 5, 517-532.

Kobe RK, Vriesendorp CF (2011) Conspecific density dependence in seedlings varies with species shade tolerance in a wet tropical forest. Ecology Letters, 14, 503-510.

Kochummen KM, LaFrankie JV, Manokaran N (1990) Floristic composition of Pasoh Forest Reserve, a lowland rain forest in Peninsular Malaysia. Journal of Tropical Forest Science, 3, 1-13.

Ley-López JM, Ávalos G, Chacón-Madrigal E (2016) Seedling growth and survival of five tree species in secondary forests and adjacent pastures in the montane rain forests of southern Costa Rica. Revista de Biología Tropical, 64, 1565-1583.

Lin F, Comita LS, Wang XG, Bai XJ, Yuan ZQ, Xing DL, Hao ZQ (2014) The contribution of understory light availability and biotic neighborhood to seedling survival in secondary versus old-growth temperate forest. Plant Ecology, 215, 795-807.

Lin LX, Comita LS, Zheng Z, Cao M (2012) Seasonal differentiation in density-dependent seedling survival in a tropical rain forest. Journal of Ecology, 100, 905-914.

Liu HM, Yang QS, Fang XF, Ma ZP, Shen GC Zhang ZG, Wang ZH, Wang XH (2015) Influences on gap species richness in a subtropical evergreen broadleaved forest. Biodiversity Science, 23, 149-156. (in Chinese with English abstract) [刘何铭, 杨庆松, 方晓峰, 马遵平, 沈国春, 张 志国, 王樟华, 王希华 (2015) 亚热带常绿阔叶林林窗物 种丰富度的影响因素. 生物多样性, 23, 149-156.]

Lu JM, Johnson DJ, Qiao XJ, Lu ZJ, Wang QG, Jiang MX (2015) Density dependence and habitat preference shape seedling survival in a subtropical forest in central China. Journal of Plant Ecology, 8, 568-577.

McCarthy-Neumann S, Kobe RK (2010) Conspecific and heterospecific plant-soil feedbacks influence survivorship and growth of temperate tree seedlings. Journal of Ecology, 98, 408-418.

Peters HA (2003) Neighbour-regulated mortality: the influence of positive and negative density dependence on tree 
populations in species-rich tropical forests. Ecology Letters, 6, 757-765.

Song YC, Wang XR (1995) Vegetation and Flora of Tiantong National Forest Park, Zhejiang Province. Shanghai Science and Technology Literature Press, Shanghai. (in Chinese with English summary) [宋永昌, 王祥荣 (1995) 浙江天童国家 森林公园的植被和区系. 上海科学技术文献出版社, 上 海.]

Tanouchi H, Sato T, Takeshita K (1994) Comparative studies on acorn and seedling dynamics of four Quercus species in an evergreen broad-leaved forest. Journal of Plant Research, 107, 153-159.

Turner IM (1990) Tree seedling growth and survival in a Malaysian rain forest. Biotropica, 22, 146-154.

von-Arnim A, Deng XW (1996) Light control of seedling development. Annual Review of Plant Physiology and Plant Molecular Biology, 47, 215-243.

Walters MB, Kruger EL, Reich PB (1993) Growth, biomass distribution and $\mathrm{CO}_{2}$ exchange of northern hardwood seedlings in high and low light: relationships with successional status and shade tolerance. Oecologia, 94, 7-16.

Walters MB, Reich PB (1996) Are shade tolerance, survival, and growth linked? Low light and nitrogen effects on hardwood seedlings. Ecology, 77, 841-853.

Wills C (1996) Safety in diversity. New Scientist, 149, 38-42.

Wright IJ, Westoby M (1999) Differences in seedling growth behaviour among species: trait correlations across species, and trait shifts along nutrient compared to rainfall gradients. Journal of Ecology, 87, 85-97.

Wright JS (2002) Plant diversity in tropical forests: a review of mechanisms of species coexistence. Oecologia, 130, 1-14.

Xie YB, Ma ZP, Yang QS, Fang XF, Zhang ZG, Yan ER, Wang XH (2012) Coexistence mechanisms of evergreen and deciduous trees based on topographic factors in Tiantong region, Zhejiang Province, eastern China. Biodiversity Science, 20, 159-167. (in Chinese with English abstract) [谢 玉涁, 马遵平, 杨庆松, 方晓峰, 张志国, 阎恩荣, 王希 华 (2012) 基于地形因子的天童地区常绿树种和落叶树 种共存机制研究. 生物多样性, 20, 159-167.]
Xiong S, Nilsson C (1997) Dynamics of leaf litter accumulation and its effects on riparian vegetation: a review. Botanical Review, 63, 240-264.

Yan ER, Wang XH, Huang JJ (2006) Shifts in plant nutrient use strategies under secondary forest succession. Plant and Soil, 289, 187-197.

Yang QS, Ma ZP, Xie YB, Zhang ZG, Wang ZH, Liu HM, Li P, Zhang N, Wang DL, Yang HB, Fang XF, Yan ER, Wang XH (2011) Community structure and species composition of an evergreen broadleaved forest in Tiantong's 20 ha dynamics plot, Zhejiang Province, eastern China. Biodiversity Science, 19, 215-223. (in Chinese with English abstract) [杨庆松, 马遵平, 谢玉涁, 张志国, 王樟华, 刘 何铭, 李萍, 张娜, 王达力, 杨海波, 方晓峰, 阎恩荣, 王 希华 (2011) 浙江天童20 ha常绿阔叶林动态监测样地的 群落特征. 生物多样性, 19, 215-223.]

Zahawi RA, Eckert C, Chaves-Fallas JM, Schwanitz L, Rosales JA, Holl KD (2015) The effect of restoration treatment soils and parent tree on tropical forest tree seedling growth. Open Journal of Forestry, 5, 154.

Zhang N, Wang XH, Zheng ZM, Ma ZP, Yang QS, Fang XF, Xie YB (2012) Spatial heterogeneity of soil properties and its relationships with terrain factors in broadleaved forest in Tiantong of Zhejiang Province, East China. Chinese Journal of Applied Ecology, 23, 2361-2369. (in Chinese with English abstract) [张娜, 王希华, 郑泽梅, 马遵平, 杨庆 松, 方晓峰, 谢玉涁 (2012) 浙江天童常绿阔叶林土壤的 空间异质性及其与地形的关系. 应用生态学报, 23, 2361-2369.]

Zhu Y, Mi XC, Ma KP (2009) A mechanism of plant species coexistence: the negative density-dependent hypothesis. Biodiversity Science, 17, 594-604. (in Chinese with English abstract) [祝燕, 米湘成, 马克平 (2009) 植物群落物种共 存机制: 负密度制约假说. 生物多样性, 17, 594-604.]

Zuur A, Ieno EN, Walker N, Saveliev AA, Smith GM (2009) Mixed Effects Models and Extensions in Ecology with R. Springer Science \& Business Media, New York.

ЯрошенкоПД (translated by Fu ZZ) (1966) Geobotany, pp. 408. Science Press, Beijing. (in Chinese) [傅子桢 (译) (1966) 地植物学, pp. 408. 科学出版社, 北京.]

\section{附录 Supplementary Material}

\section{附录1 天童20 ha样地内定居幼苗的照片}

Appendix 1 The photo of established seedling in 20 ha forest dynamics plot in Tiantong http://www.biodiversity-science.net/fileup/PDF/2016290-1.pdf

\section{附录2 天童20 ha样地内定居幼苗的物种组成}

Appendix 2 Species composition of established seedlings in 20 ha forest dynamics plot in Tiantong http://www.biodiversity-science.net/fileup/PDF/2016290-2.pdf 
附录3 公式

Appendix 3 Equations

http://www.biodiversity-science.net/fileup/PDF/2016290-3.pdf

附录4 物种平均相对生长速率与潜在影响因子组合后作为生长影响因素模型固定项时的pseudo-R-squared和估计参数

Appendix 4 The pseudo-R-squared and estimator of combined fixed factors including species' average relative growth rate factor and each potential impact factor in seedling growth mechanism model

http://www.biodiversity-science.net/fileup/PDF/2016290-4.pdf

附录5 天童20 ha样地内定居幼苗存活率与相对生长速率的相关关系。(a)为定居幼苗多度大于50, 频度大于40的 8 个优势物 种在不同幼苗样方内的年存活率与平均相对生长速率间的关系; (b)为所有物种在不同幼苗样方内的年存活率与平均生长速 率间的关系。

Appedix 5 Relationship between survival rate and relative growth rate of established seedlings in 20 ha forest dynamics plot in Tiantong. (a) represents the relationship between annual survival rate and mean relative growth rate of established seedlings of dominant species (abundance is more than 50 and frequency is more than 40) in seedling plots; (b) represents the relationship between annual survival rate and mean relative growth rate of established seedlings of the whole species in seedling plots.

http://www.biodiversity-science.net/fileup/PDF/2016290-5.pdf

附录6 潜在影响因子的pseudo-R-squared

Appendix 6 The pseudo-R-squared of potential impact factors http://www.biodiversity-science.net/fileup/PDF/2016290-6.pdf 
刘何铭, 马遵平, 杨庆松, 方晓峰, 林庆凯, 宗意, 阿尔达克·阿庆, 王希华. 天童常绿阔叶林定居幼苗存活 和生长的关联. 生物多样性, 2017, 25 (1): 11-22.

http://www.biodiversity-science.net/CN/10.17520/biods.2016290

\section{附录1 天童20 ha样地内定居幼苗的照片}

Appendix 1 The photo of established seedling in 20 ha forest dynamics plot in Tiantong

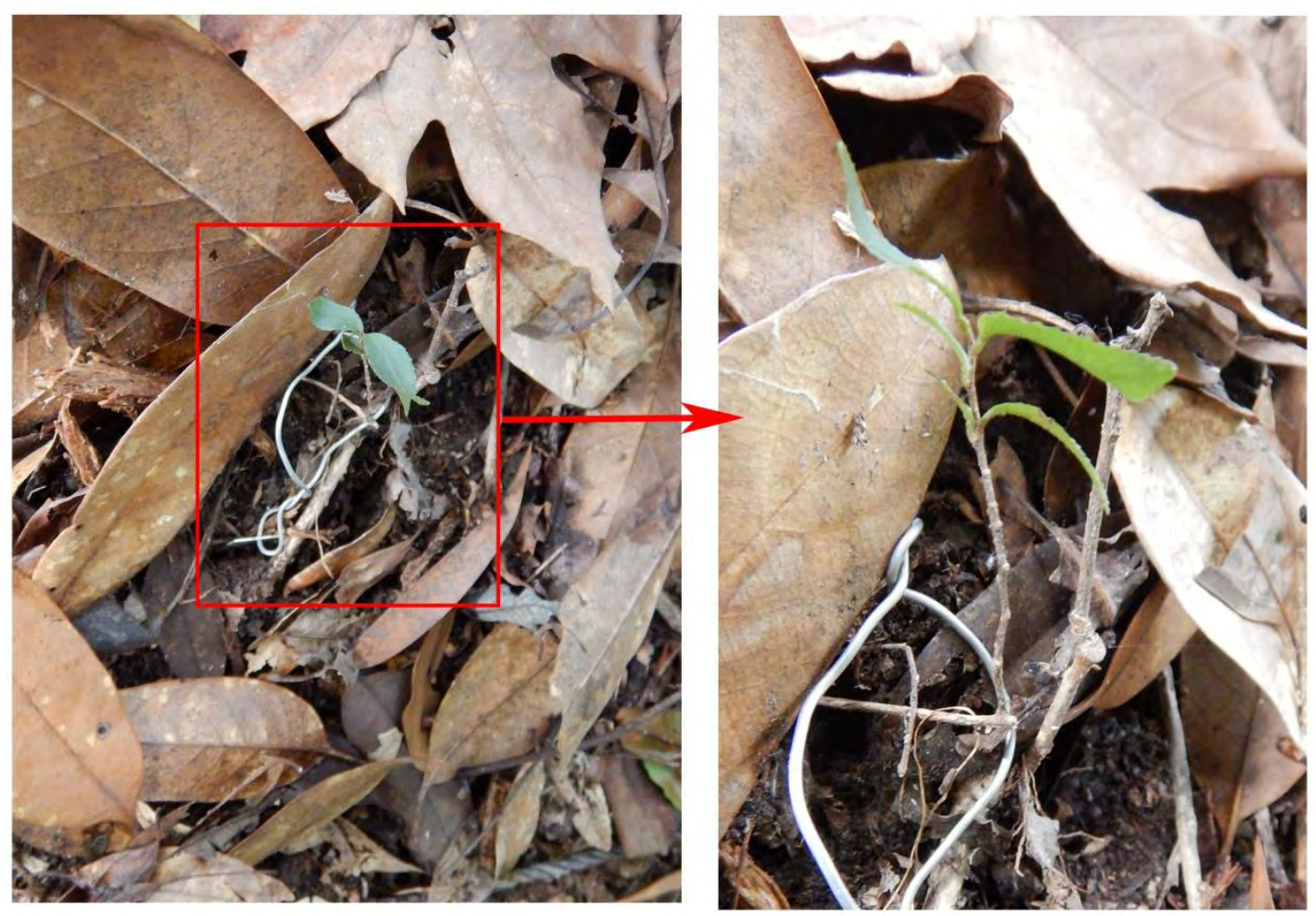


刘何铭, 马遵平, 杨庆松, 方晓峰, 林庆凯, 宗意, 阿尔达克·阿庆, 王希华. 天童常绿阔叶林定居幼苗存活 和生长的关联. 生物多样性, 2017, 25 (1): 11-22.

http://www.biodiversity-science.net/CN/10.17520/biods.2016290

附录 2 天童 20 ha 样地内定居幼苗的物种组成

Appendix 2 Species composition of established seedlings in 20 ha forest dynamics plot in Tiantong

\begin{tabular}{|c|c|c|}
\hline 种名 Species & 多度 Abundance (ind.) & $\begin{array}{l}\text { 频度 Frequency (No. of } \\
\text { seedling plots) }\end{array}$ \\
\hline 黄丹木姜子 Litsea elongata & 150 & 96 \\
\hline 杨梅叶蚊母 Distylium myricoides & 105 & 49 \\
\hline 连荵茶 Camellia fraterna & 100 & 80 \\
\hline 毛脉橴 Acer pubinerve & 72 & 44 \\
\hline 红楠 Machilus thunbergii & 71 & 47 \\
\hline 云山青冈 Cyclobalanopsis sessilifolia & 67 & 58 \\
\hline 华东楠 Machilus leptophylla & 63 & 27 \\
\hline 披针叶茴香 Illicium lanceolatum & 55 & 40 \\
\hline 细叶香桂 Cinnamomum subavenium & 53 & 43 \\
\hline 浙江新木姜子 Neolitsea aurata var.chekiangensis & 50 & 38 \\
\hline 短梗冬青 Ilex buergeri & 41 & 40 \\
\hline 茶 camellia.sinensis & 34 & 16 \\
\hline 细枝柃 Eurya loquaiana & 32 & 29 \\
\hline 长叶石栋 Lithocarpus henryi & 31 & 30 \\
\hline 栲树 Castanopsis fargesii & 25 & 21 \\
\hline 赤楠 Syzygium buxifolium & 21 & 13 \\
\hline 腺点樱 Laurocerasus phaeosticta & 14 & 14 \\
\hline 浙皖虎刺 Damnacanthus macrophyllus ${ }^{*}$ & 14 & 7 \\
\hline 木荷 Schima superba & 13 & 13 \\
\hline 山矾 Symplocos sumuntia & 11 & 10 \\
\hline 窄基红褐柃 Eurya.rubiginosa var.attenuata & 11 & 10 \\
\hline 薄叶山矾 Symplocos anomala & 10 & 10 \\
\hline 杨桐 Cleyera japonica & 9 & 9 \\
\hline 南酸本 Choerospondias axillaris & 9 & 8 \\
\hline 黄牛奶树 Symplocos laurina & 8 & 7 \\
\hline 大青 Clerodendrum cyrtophyllum & 8 & 7 \\
\hline 油桐 Vernicia fordii & 7 & 7 \\
\hline 四川山矾 Symplocos setchuensis & 7 & 7 \\
\hline 拟赤杨 Alniphyllum fortunei & 7 & 7 \\
\hline 细叶青冈 Cyclobalanopsis myrsinifolia & 7 & 6 \\
\hline 小叶青冈 Cyclobalanopsis gracilis & 7 & 5 \\
\hline 米槠 Castanopsis carlesii & 6 & 6 \\
\hline 老鼠矢 Symplocos stellaris & 6 & 6 \\
\hline 光叶山矾 Symplocos lancifolia & 6 & 6 \\
\hline 光叶石楠 Photinia glabra & 6 & 4 \\
\hline 赛山梅 Styrax confusus & 5 & 5 \\
\hline 华东木犀 Osmanthus cooperi & 5 & 5 \\
\hline 木犀 Osmanthus fragrans & 5 & 3 \\
\hline 雷公鹅耳枥 Carpinus viminea & 4 & 4 \\
\hline 花椒簕 Zanthoxylum scandens ${ }^{*}$ & 4 & 4 \\
\hline 马银花 Rhododendron ovatum & 4 & 3 \\
\hline 青冈 Cyclobalanopsis glauca & 4 & 3 \\
\hline 虎刺 Damnacanthus indicus ${ }^{*}$ & 4 & 3 \\
\hline
\end{tabular}


刘何铭, 马遵平, 杨庆松, 方晓峰, 林庆凯, 宗意, 阿尔达克·阿庆, 王希华. 天童常绿阔叶林定居幼苗存活 和生长的关联. 生物多样性, 2017, 25 (1): 11-22.

http://www.biodiversity-science.net/CN/10.17520/biods.2016290

\begin{tabular}{|c|c|c|}
\hline 柧子 Gardenia jasminoides & 4 & 2 \\
\hline 红山茶 Camellia japonica & 4 & 2 \\
\hline 白背叶 Mallotus apelta & 3 & 3 \\
\hline 红脉钓樟 Lindera rubronervia & 3 & 3 \\
\hline 虎皮楠 Daphniphyllum oldhami & 3 & 3 \\
\hline 紫楠 Phoebe sheareri & 3 & 2 \\
\hline 三尖杉 Cephalotaxus fortunei & 3 & 2 \\
\hline 黄檀 Dalbergia hupeana & 2 & 2 \\
\hline 刺叶桂樱 Laurocerasus spinulosa & 2 & 2 \\
\hline 野鸦椿 Euscaphis japonica & 2 & 2 \\
\hline 红枝柴 Meliosma oldhamii & 2 & 2 \\
\hline 铁冬青 Ilex rotunda & 2 & 2 \\
\hline 厚壳树 Ehretia thyrsiflora & 2 & 2 \\
\hline 豹皮樟 litsea coreana var.sinensis & 2 & 2 \\
\hline 华紫珠 Callicarpa cathayana & 2 & 1 \\
\hline 无患子 Sapindus mukorossi & 1 & 1 \\
\hline 西川朴 Celtis vandervoetiana & 1 & 1 \\
\hline 狗骨柴 Diplospora dubia & 1 & 1 \\
\hline 苦枥木 Fraxinus insularis & 1 & 1 \\
\hline 米饭 Vaccinium mandarinorum & 1 & 1 \\
\hline 皱柄冬青 Ilex kengii & 1 & 1 \\
\hline 总状山矾 Symplocos botryantha & 1 & 1 \\
\hline 格药柃 Eurya muricata & 1 & 1 \\
\hline 檫木 Sassafras tzumu & 1 & 1 \\
\hline 厚皮香 Ternstroemia gymnanthera & 1 & 1 \\
\hline 山鸡椒 Litsea cubeba & 1 & 1 \\
\hline 野桐 Mallotus japonicus var. floccosus & 1 & 1 \\
\hline 杨梅 Myrica rubra & 1 & 1 \\
\hline 白花苦灯笼 Tarenna mollissima & 1 & 1 \\
\hline 山合欢 Albizia kalkora & 1 & 1 \\
\hline 冬青 Ilex chinensis & 1 & 1 \\
\hline 刺楸 Kalopanax septemlobus & 1 & 1 \\
\hline 银杏 Ginkgo biloba & 1 & 1 \\
\hline 石斑木 Raphiolepis indica & 1 & 1 \\
\hline 未知 Unknown & 10 & 9 \\
\hline 总计 Total & 1,239 & \\
\hline
\end{tabular}

* 样地每木调查时未调查到成树 $(\mathrm{DBH} \geq 1 \mathrm{~cm})$ 的物种。多度为 2011 年 10 月幼苗本底调查时, 定居幼苗的数 量; 频度为包含该种定居幼苗的幼苗样方的个数。

* indicate this species' adults were not surveyed in the census of Tiantong plot in 2011. The abundance indicated the individual number of this species' established seedlings during the first census in October 2011; the frequency indicated the number of seedling plots which contain this species' established seedlings. 
刘何铭, 马遵平, 杨庆松, 方晓峰, 林庆凯, 宗意, 阿尔达克·阿庆, 王希华. 天童常绿阔叶林定居幼苗存活 和生长的关联. 生物多样性, 2017, 25 (1): 11-22.

http://www.biodiversity-science.net/CN/10.17520/biods.2016290

附录 3 公式

Appendix 3 Equations

$\sum_{i=0}^{n} C_{n}^{i}=2^{n}$

$n$ 为潜在影响因子的个数。

$$
A I C_{c}=A I C+\frac{2 K(K+1)}{N-K-1}
$$

$K$ 为模型内包含的解释变量的个数, $N$ 为样本数量。

$$
\Delta A I C_{c i}=A I C_{c i}-A I C_{c \min }
$$

$A I C_{c \min }$ 全子集回归模型的 $A I C_{c}$ 最小值。

$$
w_{i}=\frac{\exp \left(-\frac{1}{2} \Delta A I C_{c i}\right)}{\sum_{r=1}^{R} \exp \left(-\frac{1}{2} \Delta A I C_{c r}\right)}
$$

$R$ 为全子集回归模型的数量。

$$
I_{j}\left(g_{i}\right)\left\{\begin{array}{l}
1 \text { 如果潜在影响因子 } x_{j} \text { 在回归模型 } g_{i} \text { 中 } \\
0 \text { 如果潜在影响因子 } x_{j} \text { 不在回归模型 } g_{i} \text { 中 }
\end{array}\right.
$$

$$
w_{+}(j)=\sum_{i=1}^{R} w_{i} I_{j}\left(g_{i}\right)
$$


刘何铭, 马遵平, 杨庆松, 方晓峰, 林庆凯, 宗意, 阿尔达克·阿庆, 王希华. 天童常绿阔叶林定居幼苗存活 和生长的关联. 生物多样性, 2017, 25 (1): 11-22.

http://www.biodiversity-science.net/CN/10.17520/biods.2016290

$$
w_{i}^{\prime}=\frac{\exp \left(-\frac{1}{2} \Delta A I C_{c i}\right)}{\sum_{r=1}^{R 1} \exp \left(-\frac{1}{2} \Delta A I C_{c r}\right)}
$$

$R 1$ 为最优模型组内的模型数量。

$$
\begin{aligned}
& w_{+}^{\prime}(j)=\sum_{i=1}^{R 1} w_{i}^{\prime} I_{j}\left(g_{i}\right) \\
& \hat{\beta}_{j}=\frac{\sum_{i=1}^{R 1} w_{i}^{\prime} I_{j}\left(g_{i}\right) \hat{\beta}_{j, i}}{w_{+}^{\prime}(j)}
\end{aligned}
$$

$\beta_{j, i}$ 代表潜在影响因子 $x_{j}$ 在回归模型 $g_{i}$ 中的回归系数 $\beta_{j}$, 如果该潜在因子不包含在回归模型 $g_{i}$ 中, 则 $I_{j}\left(g_{i}\right)$

和 $\hat{\beta}_{j, i}$ 都为 0 ; 如果该潜在因子包含在回归模型 $g_{i}$ 中, 但回归系数与 0 没有显著性差异即 $p \geq 0.05$, 则 $\hat{\beta}_{j, i}$ 为 0 。

$$
\overline{\bar{\beta}}_{j}=\sum_{i=1}^{R 1} w_{i}^{\prime} I_{j}\left(g_{i}\right) \hat{\beta}_{j i}
$$

当 $w_{+}{ }^{\prime}(j)$ 的值为 0 时, 采用二阶平均估计量 $\tilde{\bar{\beta}}_{j}$ 替代平均估计量 $\hat{\bar{\beta}}_{j}$ 。 
刘何铭, 马遵平, 杨庆松, 方晓峰, 林庆凯, 宗意, 阿尔达克·阿庆, 王希华. 天童常绿阔叶林定居幼苗存活 和生长的关联. 生物多样性, 2017, 25 (1): 11-22.

http://www.biodiversity-science.net/CN/10.17520/biods.2016290

附录 4 物种平均相对生长速率与潜在影响因子组合后作为生长影响因素模型固定项时的 pseudo-R-squared 和估计参数

Appendix 4 The pseudo-R-squared and estimator of combined fixed factors including species' average relative growth rate factor and each potential impact factor in seedling growth mechanism model

\begin{tabular}{|c|c|c|c|c|}
\hline 固定项 Fixed factor & $R^{2}$ & 排序 & $\beta_{\overline{R G R}}$ & $\beta$ \\
\hline $\begin{array}{l}\text { 物种平均相对生长速率和同种成树的邻体指数 } \\
\text { Species’ average relative growth rate and conspecific } \\
\text { adult neighborhood indices }\end{array}$ & $2.71 \times 10^{-2}$ & 10 & $4.52 \times 10^{-2} * *$ & $2.65 \times 10^{-3}$ \\
\hline $\begin{array}{l}\text { 物种平均相对生长速率和异种成树邻体指数 } \\
\text { Species’ average relative growth rate and } \\
\text { heterospecific adult neighborhood indices }\end{array}$ & $2.70 \times 10^{-2}$ & 13 & $4.53 \times 10^{-2} * *$ & $3.07 \times 10^{-4}$ \\
\hline $\begin{array}{l}\text { 物种平均相对生长速率和同种幼苗邻体密度 } \\
\text { Density of conspecific seedling neighbors }\end{array}$ & $2.77 \times 10^{-2}$ & 2 & $4.58 \times 10^{-2} * *$ & $8.72 \times 10^{-3}$ \\
\hline $\begin{array}{l}\text { 物种平均相对生长速率和异种幼苗邻体密度 } \\
\text { Species' average relative growth rate and density of } \\
\text { heterospecific seedling neighbors }\end{array}$ & $2.71 \times 10^{-2}$ & 8 & $4.53 \times 10^{-2} * *$ & $-3.50 \times 10^{-3}$ \\
\hline $\begin{array}{l}\text { 物种平均相对生长速率和同种调落叶产量 } \\
\text { Species’ average relative growth rate and amount of } \\
\text { conspecific leaf litter }\end{array}$ & $2.72 \times 10^{-2}$ & 7 & $4.52 \times 10^{-2} * *$ & $4.01 \times 10^{-3}$ \\
\hline $\begin{array}{l}\text { 物种平均相对生长速率和异种调落叶产量 } \\
\text { Species’ average relative growth rate and amount of } \\
\text { heterospecific leaf litter }\end{array}$ & $2.74 \times 10^{-2}$ & 5 & $4.50 \times 10^{-2} * *$ & $-6.24 \times 10^{-3}$ \\
\hline $\begin{array}{l}\text { 物种平均相对生长速率和冠层开度 Species’ } \\
\text { average relative growth rate and canopy openness }\end{array}$ & $3.00 \times 10^{-2}$ & 1 & $4.32 \times 10^{-2} * *$ & $1.48 \times 10^{-2 * *}$ \\
\hline $\begin{array}{l}\text { 物种平均相对生长速率和海拔 Species' average } \\
\text { relative growth rate and elevation }\end{array}$ & $2.71 \times 10^{-2}$ & 8 & $4.50 \times 10^{-2} * *$ & $3.44 \times 10^{-3}$ \\
\hline $\begin{array}{l}\text { 物种平均相对生长速率和坡度 Species' average } \\
\text { relative growth rate and slope }\end{array}$ & $2.72 \times 10^{-2}$ & 6 & $4.53 \times 10^{-2} * *$ & $-4.34 \times 10^{-3}$ \\
\hline $\begin{array}{l}\text { 物种平均相对生长速率和坡向 Species' average } \\
\text { relative growth rate and aspect }\end{array}$ & $2.70 \times 10^{-2}$ & 11 & $4.54 \times 10^{-2} * *$ & $-2.41 \times 10^{-3}$ \\
\hline $\begin{array}{l}\text { 物种平均相对生长速率和草本覆盖度 } \\
\text { Species’ average relative growth rate and herbaceous } \\
\text { coverage }\end{array}$ & $2.76 \times 10^{-2}$ & 3 & $4.51 \times 10^{-2} * *$ & $6.88 \times 10^{-3}$ \\
\hline $\begin{array}{l}\text { 物种平均相对生长速率和全氮 Species' average } \\
\text { relative growth rate and total nitrigen }\end{array}$ & $2.70 \times 10^{-2}$ & 12 & $4.52 \times 10^{-2} * *$ & $-8.95 \times 10^{-4}$ \\
\hline $\begin{array}{l}\text { 物种平均相对生长速率和全磷 Species' average } \\
\text { relative growth rate and total phosphorus }\end{array}$ & $2.70 \times 10^{-2}$ & 14 & $4.53 \times 10^{-2} * *$ & $1.92 \times 10^{-4}$ \\
\hline $\begin{array}{l}\text { 物种平均相对生长速率和 } \mathrm{pH} \text { 值 Species' average } \\
\text { relative growth rate and } \mathrm{pH} \text { value }\end{array}$ & $2.75 \times 10^{-2}$ & 4 & $4.54 \times 10^{-2} * *$ & $-6.72 \times 10^{-3}$ \\
\hline
\end{tabular}

$\beta_{\overline{R G R}}$ 代表物种平均相对生长速率因子的估计参数; $\beta$ 代表不同的潜在影响因子的估计参数; **代表该估计 参数与 0 之间有极显著的差异。

$\beta_{\overline{R G R}}$ represents the estimator of species' average relative growth rate factor; $\beta$ represents the estimator of each potential impact factor; ** represents this estimator has a highly significant difference with 0 . 
刘何铭, 马遵平, 杨庆松, 方晓峰, 林庆凯, 宗意, 阿尔达克·阿庆, 王希华. 天童常绿阔叶林定居幼苗存活 和生长的关联. 生物多样性, 2017, 25 (1): 11-22.

http://www.biodiversity-science.net/CN/10.17520/biods.2016290

附录 5 天童 20 ha 样地内定居幼苗存活率与相对生长速率的相关关系。a 图为定居幼苗多度大于 50, 频度 大于 40 的 8 个优势物种在不同幼苗样方内的年存活率与平均相对生长速率间的关系; $\mathbf{b}$ 图为所有物种在不 同幼苗样方内的年存活率与平均生长速率间的关系。

Appedix 5 Relationship between survival rate and relative growth rate of established seedlings in 20 ha forest dynamics plot in Tiantong. Fig. a represents the relationship between annual survival rate and mean relative growth rate of established seedlings of dominant species (abundance is more than 50 and frequency is more than 40) in seedling plots; Fig. b represents the relationship between annual survival rate and mean relative growth rate of established seedlings of the whole species in seedling plots.
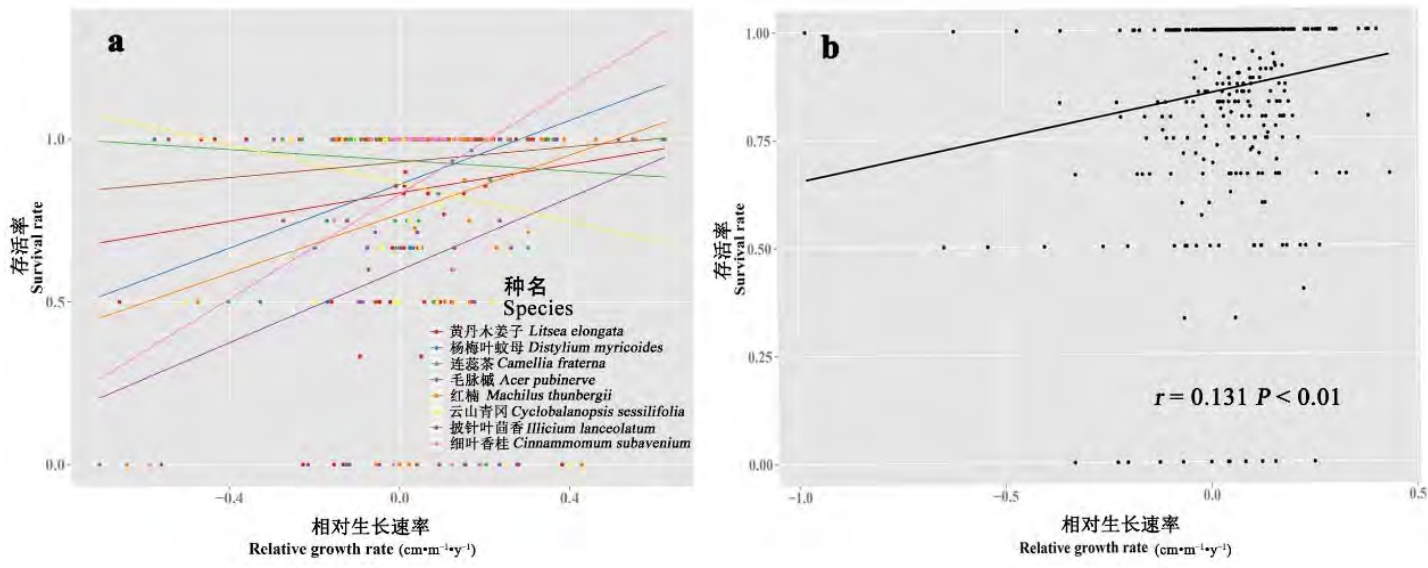
刘何铭, 马遵平, 杨庆松, 方晓峰, 林庆凯, 宗意, 阿尔达克·阿庆, 王希华. 天童常绿阔叶林定居幼苗存活 和生长的关联. 生物多样性, 2017, 25 (1): 11-22.

http://www.biodiversity-science.net/CN/10.17520/biods.2016290

附录 6 潜在影响因子的 pseudo-R-squared

Appendix 6 The pseudo-R-squared of potential impact factors

\begin{tabular}{|c|c|c|c|c|}
\hline \multirow[t]{2}{*}{ 固定项 Fixed factor } & \multicolumn{2}{|c|}{$\begin{array}{c}\text { 短期存活影响因素模型 } \\
\text { Short-term seedling survival } \\
\text { mechanism model }\end{array}$} & \multicolumn{2}{|c|}{$\begin{array}{c}\text { 生长影响因素模型 } \\
\text { Seedling growth mechanism } \\
\text { model }\end{array}$} \\
\hline & $R^{2}$ & $\begin{array}{l}\text { 排序 } \\
\text { Rank }\end{array}$ & $R^{2}$ & $\begin{array}{l}\text { 排序 } \\
\text { Rank }\end{array}$ \\
\hline $\begin{array}{l}\text { 前一年的幼苗相对生长速率 } \\
\text { Relative growth rate of seedling in the } \\
\text { previous year }\end{array}$ & $2.89 \times 10^{-2}$ & 1 & / & / \\
\hline $\begin{array}{l}\text { 同种成树的邻体指数 Conpecific adult } \\
\text { neighborhood indices }\end{array}$ & $2.85 \times 10^{-3}$ & 4 & $1.98 \times 10^{-4}$ & 9 \\
\hline $\begin{array}{l}\text { 异种成树邻体指数 Heterospecific adult } \\
\text { neighborhood indices }\end{array}$ & $1.36 \times 10^{-2}$ & 2 & $4.62 \times 10^{-11}$ & 14 \\
\hline $\begin{array}{l}\text { 同种幼苗邻体密度 Density of conspecific } \\
\text { seedling neighbors }\end{array}$ & $5.34 \times 10^{-4}$ & 9 & $6.15 \times 10^{-4}$ & 5 \\
\hline $\begin{array}{l}\text { 异种幼苗邻体密度 Density of } \\
\text { heterospecific seedling neighbors }\end{array}$ & $3.16 \times 10^{-3}$ & 3 & $1.63 \times 10^{-4}$ & 11 \\
\hline $\begin{array}{l}\text { 同种凋落叶产量 Amount of conspecific } \\
\text { leaf litter }\end{array}$ & $6.30 \times 10^{-4}$ & 8 & $3.05 \times 10^{-4}$ & 7 \\
\hline $\begin{array}{l}\text { 异种调落叶产量 Amount of } \\
\text { heterospecific leaf litter }\end{array}$ & $1.63 \times 10^{-4}$ & 12 & $1.12 \times 10^{-3}$ & 2 \\
\hline 冠层开度 Canopy openness & $5.85 \times 10^{-9}$ & 15 & $5.34 \times 10^{-3}$ & 1 \\
\hline 海拔 Elevation & $2.29 \times 10^{-4}$ & 11 & $6.57 \times 10^{-4}$ & 4 \\
\hline 坡度 Slope & $2.59 \times 10^{-4}$ & 10 & $2.79 \times 10^{-4}$ & 8 \\
\hline 坡向 Aspect & $2.52 \times 10^{-3}$ & 5 & $1.70 \times 10^{-5}$ & 13 \\
\hline 草本覆盖度 Herbaceous coverage & $7.44 \times 10^{-5}$ & 13 & $9.09 \times 10^{-4}$ & 3 \\
\hline 全氮 Total nitrigen & $3.95 \times 10^{-5}$ & 14 & $1.29 \times 10^{-4}$ & 12 \\
\hline 全磷 Total phosphorus & $2.32 \times 10^{-3}$ & 6 & $1.93 \times 10^{-4}$ & 10 \\
\hline $\mathrm{pH}$ 值 $\mathrm{pH}$ value & $8.62 \times 10^{-4}$ & 7 & $4.52 \times 10^{-4}$ & 6 \\
\hline
\end{tabular}

/代表该因子无法成为该模型的固定项; 坡向经 $\cos (\alpha)+1.1$ 转换。

/ represents this factor could not be a fixed factor in that model; aspect transformed by $\cos (\alpha)+1.1$. 